\title{
ANTHROPIC EFFECTS ON THE MEIOFAUNA AND PHYSICOCHEMICAL CHARACTERISTICS OF THE HYPORHEIC ZONE IN A MEDITERRANEAN STREAM
}

\author{
SIMÓN ASTIZ ${ }^{1,2, *}$ and FRANCESCO SABATER ${ }^{3}$ \\ ${ }^{1}$ Instituto de Recursos Naturales, Universidad Simón Bolívar, Caracas 1080-A, Venezuela \\ 2 Doctorado en Ciencias y Tecnologías Ambientales, Universidad Autónoma de Barcelona, 08193 Bellaterra, España \\ ${ }^{3}$ Departamento de Ecología, Universidad de Barcelona, 08028 Barcelona, España \\ *Corresponding author: e-mail: sastiz@usb.ve
}

\begin{abstract}
We examined the effects of the discharge from a wastewater treatment plant (WWTP) on the interstitial water chemistry and structure of the hyporheos in two sections of the La Tordera stream, one upstream and one downstream of the effluent from the treatment plant. Interstitial water samples were collected to determine the vertical hydraulic gradient (VHG) and hydraulic conductivity (K) at six sites in each of the two sections on six occasions between November 2006 and September 2007. Samples of the interstitial meiofauna were collected in upwelling zones in both sections of the river. There were no patterns in the hydraulic gradient either in its direction or its magnitude along the longitudinal axis. There were no differences in VHG recorded at the sites sampled indicating that the two sections were similar in terms of geomorphology. The hydraulic conductivity was greatest in the control section (upstream of the effluent) of the stream. There were no significant differences in specific conductance, phosphates, nitrates or ammonia in the upwelling and downwelling zones. In the upwelling zones in the section of the river downstream from the effluent the concentrations of nitrates were greater than in the downwelling zones, but levels of phosphates and ammonia were lower. There was a decrease in the interstitial nutrient concentrations along a longitudinal gradient downstream of the effluent. A total of 24 taxa were collected from the hyporheos, with Chironomids and Oligochaetes being the most abundant groups. A higher Shannon diversity index (2.86) was recorded in the downstream section of the river even though a greater taxa richness (18) was recorded in the control section. This is probably due to the fact that a larger number of rare or unusual species was found in this section. According to the BMWP biological index the water quality in the control and downstream sections was polluted and heavily polluted, respectively. The shifts in hydraulic exchange processes and the bio-physicochemical environment of the hyporheic zone are the main effects of the discharge from the Santa Maria Palautordera wastewater treatment plant on the two sections of the river studied.
\end{abstract}

Keywords: point source, invertebrates, hyporheic zone, hydraulic gradient, BMWP index

\section{Introduction}

Fluvial ecosystems in developed regions are subject to high environmental stress due to eutrophication (Fisher et al. 1998). Human activities may cause land use changes in catchment areas or modifications of the landscape that increase the transport of nutrients towards aquifers and surface water. Water courses (rivers and streams) may also be directly affected by discharges of waste water (point sources) and other modifications, which reduce their capacity to respond to an increase in nutrient concentrations. These problems are accentuated in Mediterranean rivers due to the persistent scarcity of water (Martí and Sabater 1996; Cushing and Allan 2001). Point sources of pollution of surface water bodies, for example, discharges from water treatment plants (sewage), industrial installations or high intensity precipitations, which frequently contribute high loads of pollution that affect the quality of river water, are an expected or derived consequence of urban and industrial development. In addition, and depending on the relative volumes of the effluent and the river, the discharge from a sewage works can represent an important percentage of the river volume downstream of the effluent. These factors act at different scales ranging from a particular stretch of a river to the whole catchment area. Contaminants in fluvial ecosystems may affect the quality of the groundwater in several ways: firstly, in those areas where the river loses water to the aquifer (downwelling); secondly, along sections where the aquifer is very deep, favouring the infiltration of surface water, and thirdly, during periods of flooding when the river water spreads over the floodplain. The concentrations of these contaminants may, however, be reduced by biogeochemical processes, which take place in shallow aquifers and the hyporheic zone (Boulton et al. 1997; Fuller and Harvey 1999; USGS 2001).

Since 1950 aquatic ecologists have emphasized the importance of the interaction between surface water and groundwater in the functioning of aquatic ecosystems. The region where the water in the aquifer and the river mix is known as the hyporheos and is important in that in its sediments there are diverse, metabolically active microbial communities, which retain and transform essential biological elements. There are few studies on the influence of the hyporheos on fluvial ecosystem metabolism, but some conceptual models propose that this depends on the type and metabolic rate of the microbial communities, the proportion of the river volume that flows through them and their influence on hydrological residence times (Triska et al. 1989a; Fellows et al. 2001). The hyporheic zone can have a very dynamic flow regimen. At maximum volume or flooding peaks, water flows from the surface to the subsurface, recharging the aquifer. At low volumes, however, water flows from 
the aquifer into the river, providing the main contribution to the basal volume of most rivers. The recharge and discharge zones are more abundant where the bottoms of rivers consist of coarse sediments rather than sand. Studies of the changes in fluvial geomorphology along a longitudinal profile have produced a model in which areas of recharge (downwelling) alternate with areas of discharge (upwelling). When the depth of the water channel decreases, high pressure zones are produced where the river bed starts to rise (riffle), into which water flows, displacing the interstitial water and flowing under the river bed to the opposite end of the riffle where the increase in depth produces a low pressure zone (pool) and the water in the hyporheos comes to the surface (upwelling zone). The alternating flow model describes a gradient of physicochemical conditions between the river and groundwater, where biochemical processes, together with the hydraulic residence time in the zone, also interact. In general, the concentration of nutrients in the hyporheic water is significantly higher than in the surface water. Given the importance of nutrients in production processes, a reserve of these in the hyporheos could be of fundamental importance in the metabolic processes of fluvial ecosystems (Sabater and Vila 1991; Franken et al. 2001).

Nutrient retention is a function of the fluvial ecosystems that could contribute to the recovery of water quality in contaminated rivers. This is governed by the interaction between physicochemical and biological factors, among the most important being the topography of the river bed, the thickness of the hyporheic layer, hydrological factors, etc. Depending on prevailing conditions, however, some of these factors will take precedence over others. The exchange of water and nutrients in the hyporheic zone results in a reduction in the transport of certain elements, whether due to physicochemical transformations or microbiological absorption, making this exchange zone, or surface/subsurface transition zone of vital importance for the optimization of the auto-regenerating capacity of those rivers considered to be pristine. Some years ago, Jones and Holmes (1996) reported that the underlying hyporheic zone acted as a source of nitrates in nitrogen deficient streams, but as a sink in streams with high nitrogen concentrations. In addition, Hill et al. (1998) suggest that in streams with high nitrogen concentrations the retention of nitrates is particularly affected by the size of the surface water retention zone. A larger retention zone has a longer residence time, resulting in increased contact with those sites adjacent to the surface/subsurface interphase where the exhaustion of nitrates occurs. This capacity for physical and biological nutrient retention can be modified by changes in the morphology of the river channel or the permeability of the sediment, or by increases in the nutrient load from point sources of contamination, such as effluents from wastewater treatment plants. This increase in the availability of macronutrients, such as nitrogen and phosphorus, produces an increase in the primary productiv- ity of the system and may accelerate the obstruction or clogging of the interstitial spaces in the sediment, consequently reducing the exchange of elements in the surface / aquifer interphase. Taking into consideration these ideas the aim of this study was to evaluate the effects of the effluent from an urban wastewater treatment plant on the meiofauna and physicochemical characteristics of the hyporheic zone along the La Tordera River.

\section{Material and Methods}

\section{Study Area}

The catchment area of the La Tordera river is located in Cataluña, Northeast Spain, and extends over $868.5 \mathrm{~km}^{2}$ (Fig. 1). Owing to the Mediterranean climate it has a low average annual precipitation of about $805.6 \mathrm{~mm}$ irregularly distributed throughout the year with spring and autumn being the wettest seasons, and an average annual discharge at its mouth of $3.17 \mathrm{~m}^{3} \mathrm{~s}^{-1}$. The hydric balance of the catchment is positive with a net annual gain of between 70 and $80 \mathrm{hm}^{3}$ distributed in zones tending towards a deficit and others tending towards an excess. Due to the proximity of the catchment basin to the coast it has been intensively settled and developed, with a population higher than the average for the country. This has resulted in a series of environmental disturbances, such as water pollution, the occupation of the alluvial plain, the destabilization of the natural fluvial dynamics and the overexploitation of surface and underground watercourses (Albiol 2002). The experimental sub-catchment within the La Tordera drainage basin was selected because of the location of a WWTP (Santa María de Palautordera), which discharges polluted water into the river, dividing it into two sub-reaches, upstream (control section) and downstream (altered section) of the effluent, thus permitting us to investigate the effect of the effluent on the functioning of the surface and subsurface ecosystems (Fig. 1). In La Tordera, land use within the sub-catchment located upstream of the section of the river studied (7024 inhabitants and $80.4 \mathrm{~km}^{2}$ ) there is $87.4 \%$ forest and open land, $10.8 \%$ arable and grassland and $1.8 \%$ urban, of which the latter is concentrated in the lower part of the basin. Each experimental section was approximately $100 \mathrm{~m}$ long, with a substrate mainly of cobbles (34\%), pebbles (22\%) and boulders (22\%). The WWTP discharges into La Tordera stream the result of treating 5808 inhabitant-equivalents, where 1 inhabitant-equivalent is the biodegradable organic matter load equivalent to a $\mathrm{BOD}_{5}$ of $60 \mathrm{~g} \mathrm{O}_{2}$ day $^{-1}$. This particular WWTP uses the activated sludge method to treat the waste water but lacks the technology to actively remove nitrogen or phosphorus. As regards the biological communities present, Diatoms dominate the microbiota and the most abundant macroinvertebrate families in the spring months are Baetidae, Ephemerellidae, Chironomidae, Simuliidae, Oligochaeta and Ancylidae (Prat 2001). 

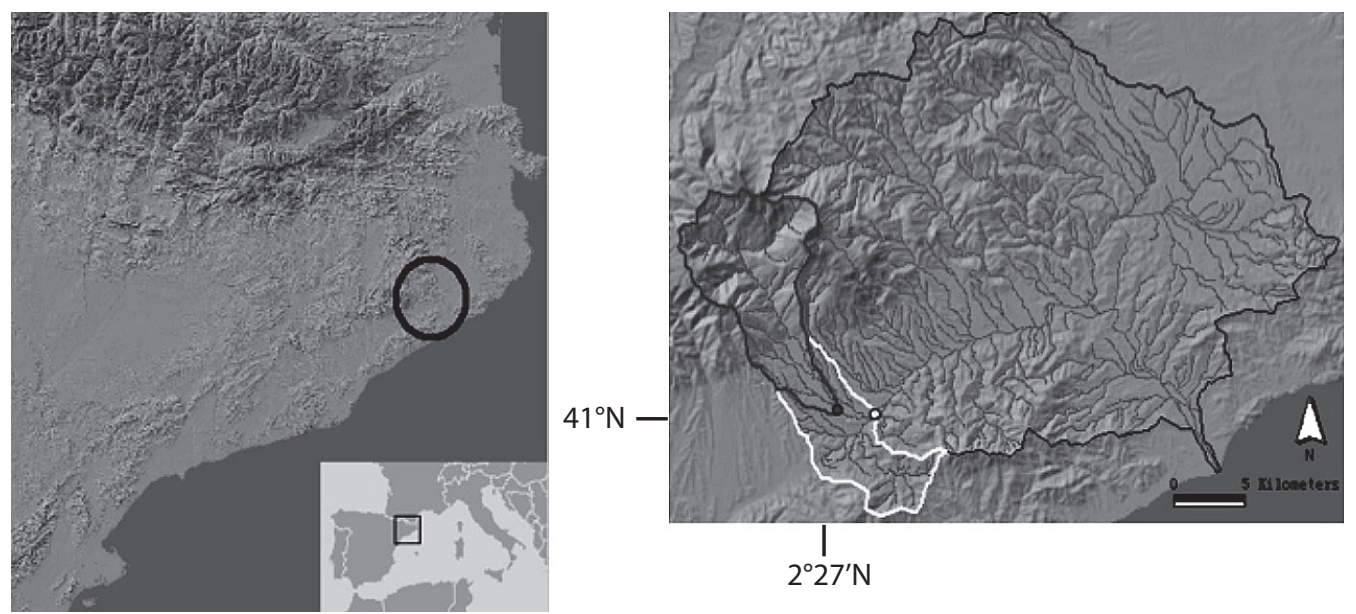

It in Altitude (m a. s. I.)

WWTP

Catchment

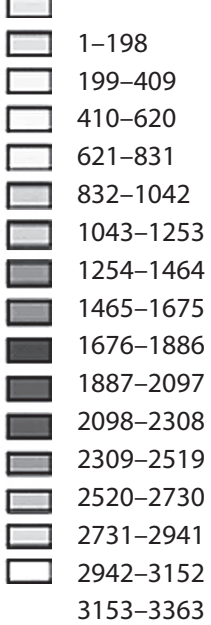

O Physicochemistry

Subcatchment

Fig. 1 Location of the La Tordera catchment area and the sub catchment (in grey) associated with the presence of the wastewater treatment plant The area inside the white line is monitored by a physicochemical monitoring station.

Water samples were collected in triplicate from the hyporheic zone in the center of six transects located at intervals of $10 \mathrm{~m}$ along the two experimental sections during a hydrological year. Samples were collected using a drive-in metallic tube, $16 \mathrm{~mm}$ wide and $50 \mathrm{~cm}$ long, driven into the river bed to a depth of approximately $25 \mathrm{~cm}$. A narrower tube of transparent plastic with a series of holes in the end pointing towards the river bed was then introduced inside the metal tube and interstitial water was pumped into it to a predetermined level (mini-well) using a peristaltic pump, discarding the first lot of excessively turbid samples. Once a volume of relatively transparent water was obtained, the temperature and specific conductivity (K25) of both it and the surface water adjacent to it, were determined. The samples were then immediately filtered through Whatman GF/F fiber glass filters, with a $0.7 \mu \mathrm{m}$ pore size, and refrigerated until their analyzed in the laboratory. The dissolved reactive phosphorus was analyzed using a colorimetric method using molybdenum blue (APHA 1989) and the $\mathrm{NO}_{3}-\mathrm{N}$, $\mathrm{NO}_{2}-\mathrm{N}$ and $\mathrm{NH}_{4}-\mathrm{N}$ were analyzed automatically using a model II Technicon.

The Vertical Hydraulic Gradient (VHG) and Hydraulic Conductivity $(\mathrm{K})$ were calculated for all transects in both sections. VHG was calculated by measuring the water levels inside the mini-well (piezometer) and the river surface, and then using the VHG equation to give both positive or negative values and thus the direction of surface/subsurface exchange. Hydraulic conductivity was calculated by filling the piezometer with river water using a plastic jug, and then measuring the time it took to empty to a certain level within the tube. This measurement was repeated three times and the data were then used in the respective equation.

The hyporheic fauna were collected from the intermediate zone of three transects (1,2 and 3$)$ in both experi- mental sections of the river in July. For this, a hydraulic metal tube with a mechanical water pump attached to the end of it was driven into the river bed to a depth of approximately $30-40 \mathrm{~cm}$. Then, 501 of hyporheic water was pumped into the tube through a $100 \mu \mathrm{m}$ mesh sieve. The sieve was then washed in a plastic tray and the invertebrate sample collected placed in a plastic recipient where it was preserved and stained with rose Bengal. Samples were fully analyzed in the laboratory and organisms were identified to the taxonomic family level using the keys of Thorp and Covich (1991) and Merritt and Cummins (1978) which has been accepted as an excellent taxonomic category in most studies of biological indices of water quality (Barbour et al. 1992; Chesman 1995; Zamora and Alba-Tecedor 1996).

\section{Formulas and Calculations}

\section{Vertical Hydraulic Gradient (VHG) (cm)}

This parameter was obtained by dividing the difference between the water level inside the piezometer and the level of the river surface $(\Delta l)$ between the depths of insertion of the piezometer in the sediment $\left(h_{\text {sed }}\right)$ (Baxter et al. 2003):

$$
V H G=\Delta l h_{\text {sed }}{ }^{-1}
$$

\section{Hydraulic Conductivity $(K)\left(\mathrm{cm} \mathrm{s}^{-1}\right)$}

This parameter was calculated using Darcy's equation, which is based on the change in the position of the meniscus in the piezometer over a certain time and distance (Landon et al. 2001):

$$
K=\left[L\left(t_{1}-t_{0}\right)^{-1}\right] \ln \left[\left(H_{0} H_{1}^{-1}\right)\right]
$$


where $L$ is the segment of sediment under study and $\mathrm{t}$ is the time taken by the falling meniscus to cover the specified distance $H$. The data were analyzed using routine statistics (mean and variance). Paired t-tests were used to compare the means of the respective variables.

\section{Data Analysis}

All data were log-transformed prior to statistical analyses in order to stabilize variances and normalize the data sets. For the two sections studied we evaluated the effect of the effluent and the vertical hydraulic gradient $(V H G)$ on the hyporheic habitat (nutrient concentrations, conductivity, temperature, hydraulic conductivity $(K)$ and invertebrate assemblages) by comparing these parameters in the two sections sampled and upwelling - downwelling zones located upstream and downstream of the WWTP input using paired $t$-tests. The significance level used for all statistical tests was $p \leq 0.05$. The statistical analyses were performed using Sigma Plot 2000 for Windows statistical package. Hyporheic community parameters were used to compare invertebrate assemblages by higher groups (taxa richness $(S)$, Shannon-Wiener diversity $\left(H^{\prime}\right)$, Jaccard's index) since there is evidence of a high correlation between the number of families and the number of species in different groups of organisms (Williams et al. 1997) and hyporheic BMWP index to compare water quality between the two sections. These analyses were performed using the statistical package InfoStat 1.2 for Windows, 2008. A between-groups principal component analysis (PCA) was used to assess spatial variation in hyporheic composition (Datry et al. 2007). Between-groups PCAs generate axes corresponding to the center of gravity for all the groups, which provides a representation of the spatial discrimination of sections. Taxa for which individuals comprised $\geq 2 \%$ of the entire dataset were included in the analysis. Invertebrate abundances were $\log _{10}(x+1)$ transformed prior to analysis. These analyses were carried out using InfoStat 1.2 for Windows.

\section{Results}

\section{Comparison of Wastewater Treatment Plant Effluent and Stream Flow in Terms of Nutrient Loads}

The values for the WWTP outflow were lower than for the discharge of the stream (0.02 and 0.065 up / 0.083 down $\mathrm{m}^{3} \mathrm{~s}^{-1}$, respectively) (Table 1 ). In La Tordera the WWTP effluent represented $100 \%$ of the stream discharge in August, September and October because the stream was completely dry upstream of the input. In contrast, the input only represented 3\% of the stream flow when the stream discharge was at its highest. On average, the effluent made up 38\% of the stream flow. Mean concentrations of $\mathrm{NO}_{3}-\mathrm{N}$ and $\mathrm{PO}_{4}-\mathrm{P}$ in the effluent were higher than in the stream $\left(10.0,3.0\right.$ and $4.11,0.54 \mathrm{mg} \mathrm{l}^{-1}$ respectively). The QOD and BOD (35.0 and $14.0 \mathrm{mg}$ $\mathrm{O}_{2} 1^{-1}$, respectively) of the effluent indicated a significant input of organic matter into the stream (Table 1).

\section{Hydrology and Chemistry of the Hyporheic Zone}

There were successive zones in the vertical hydraulic gradients (VHG) of the upwelling and downwelling zones in both sections of the river (Fig. 2), with the mean values of the control being greater $(0.192$ and $\left.-0.101 \mathrm{~cm} \mathrm{~cm}^{-1}\right)$ than those of the altered section $(0.101$ and $-0.096 \mathrm{~cm} \mathrm{~cm}^{-1}$ ) (Table 2). There were no significant differences in VHG values for the six transects (spatial variation) or the two sections of the river $(p>0.05)$. The average value of the hydraulic conductivity $(K)$ recorded in the altered section was lower than recorded in the control section (Fig. 3), but it could not be measured in three transects of the control section due to the high permeability of the substrate, which was composed mainly of gravel and rock. When these extreme values for the control were removed, no significant differences between the two sections of the river were recorded and $\mathrm{K}$ varied between 46.33 and $51.18 \mathrm{~cm} \mathrm{~s}^{-1}$.

Table 1 Water temperature, hydromorphological features and indices of water quality recorded in La Tordera. Table compares data from upstream and downstream of the WWTP, with that of the WWTP effluent.

\begin{tabular}{|l|c|c|c|}
\hline \multirow{2}{*}{ Parameter } & \multicolumn{2}{|c|}{ La Tordera } & WWTP effluent \\
\cline { 2 - 4 } & (upstream of WWTP) & $-\mathrm{b}$ & 20.5 \\
\hline Temperature $\left.{ }^{\circ} \mathrm{C}\right)$ & 17.9 & - & 6.33 \\
\hline Width $(\mathrm{m})^{\mathrm{a}}$ & 6.75 & - & 0.11 \\
\hline Depth $(\mathrm{m})^{\mathrm{a}}$ & 0.09 & - & 0.14 \\
\hline Velocity $\left(\mathrm{m} \mathrm{s}^{-1}\right)^{\mathrm{a}}$ & 0.13 & 0.02 & 0.083 \\
\hline Discharge $\left(\mathrm{m}^{3} \mathrm{~s}^{-1}\right)^{\mathrm{a}}$ & 0.065 & 35 & - \\
\hline $\mathrm{QOD}\left(\mathrm{mg} \mathrm{O}_{2} \mathrm{l}^{-1}\right)$ & - & 14 & - \\
\hline $\mathrm{BOD}\left(\mathrm{mg} \mathrm{O}_{2} \mathrm{l}^{-1}\right)$ & - & 10 & 2.57 \\
\hline $\mathrm{NO}_{3}-\mathrm{N}\left(\mathrm{mg} \mathrm{N} \mathrm{I}^{-1}\right)$ & 2.71 & 3 & 0.33 \\
\hline $\mathrm{PO}_{4}-\mathrm{P}\left(\mathrm{mg} \mathrm{P} \mathrm{I}^{-1}\right)$ & 0.08 & & \\
\hline
\end{tabular}

a According to Ortiz et al. 2006.

b No data available. 
Table 2 Hydraulic and physicochemical characteristics of the water at the surface and the discharge (upwelling) and recharge (downwelling) zones in the two sections of the river studied. Mean values (+/- standard deviation).

\begin{tabular}{|c|c|c|c|}
\hline \multirow{2}{*}{ Parameter } & \multicolumn{3}{|c|}{ Control section (upstream of WWTP) } \\
\hline & Surface & Upwelling & Downwelling \\
\hline $\mathrm{K}\left(\mathrm{cm} \mathrm{s}^{-1}\right)$ & $46.33(35.27)$ & & \\
\hline VHG $\left(\mathrm{cm} \mathrm{cm}^{-1}\right)$ & & $0.192(0.192)$ & $-0.101(0.126)$ \\
\hline Temperature $\left({ }^{\circ} \mathrm{C}\right)$ & $14.16(3.96)$ & $15.58(4.15)$ & $13.82(3.78)$ \\
\hline Conductivity $\left(\mu \mathrm{S} \mathrm{cm}^{-1}\right)$ & $155.74(25.42)$ & $157.43(26.49)$ & $162.21(25.84)$ \\
\hline PO4 (mgl l-1) & $0.08(0.02)^{a}$ & $0.07(0.06)$ & $0.08(0.06)$ \\
\hline $\mathrm{NO3}\left(\mathrm{mg} \mathrm{l}^{-1}\right)$ & $2.71(0.27)^{\mathrm{a}}$ & $6.17(2.32)$ & $6.20(2.7)$ \\
\hline $\mathrm{NO} 2\left(\mathrm{mg} \mathrm{l}^{-1}\right)$ & $0.21^{\mathrm{a}}$ & $0.02(0.01)$ & $0.03(0.04)$ \\
\hline \multirow[t]{2}{*}{$\mathrm{NH} 4\left(\mathrm{mg} \mathrm{l}^{-1}\right)$} & $0.28(0.14)^{\mathrm{a}}$ & $0.05(0.02)$ & $0.04(0.01)$ \\
\hline & \multicolumn{3}{|c|}{ Altered Section (downstream of WWTP) } \\
\hline $\mathrm{K}\left(\mathrm{cm} \mathrm{s}^{-1}\right)$ & $51.18(43.41)$ & & \\
\hline VHG $\left(\mathrm{cm} \mathrm{cm}^{-1}\right)$ & & $0.101(0.079)$ & $-0.096(0.131)$ \\
\hline Temperature $\left({ }^{\circ} \mathrm{C}\right)$ & $15.82(3.99)$ & $14.79(4.35)$ & $16.44(3.82)$ \\
\hline Conductivity $\left(\mu \mathrm{S} \mathrm{cm}^{-1}\right)$ & $215.0(65.75)$ & $215.48(54.67)$ & $208.08(68.11)$ \\
\hline $\mathrm{PO} 4\left(\mathrm{mg} \mathrm{l}^{-1}\right)$ & $0.33(0.12)^{\mathrm{a}}$ & $0.37(0.37)$ & $0.57(0.47)$ \\
\hline $\mathrm{NO3}\left(\mathrm{mg} \mathrm{l}^{-1}\right)$ & $2.57(0.3)^{\mathrm{a}}$ & $11.44(2.7)$ & $9.5(3.3)$ \\
\hline $\mathrm{NO} 2\left(\mathrm{mg} \mathrm{l}^{-1}\right)$ & $0.05^{a}$ & $0.1(0.1)$ & $0.1(0.1)$ \\
\hline $\mathrm{NH} 4\left(\mathrm{mg} \mathrm{l}^{-1}\right)$ & $1.59(0.4)^{a}$ & $0.2(0.2)$ & $0.2(0.2)$ \\
\hline
\end{tabular}

a According to Merseburger et al. 2005.
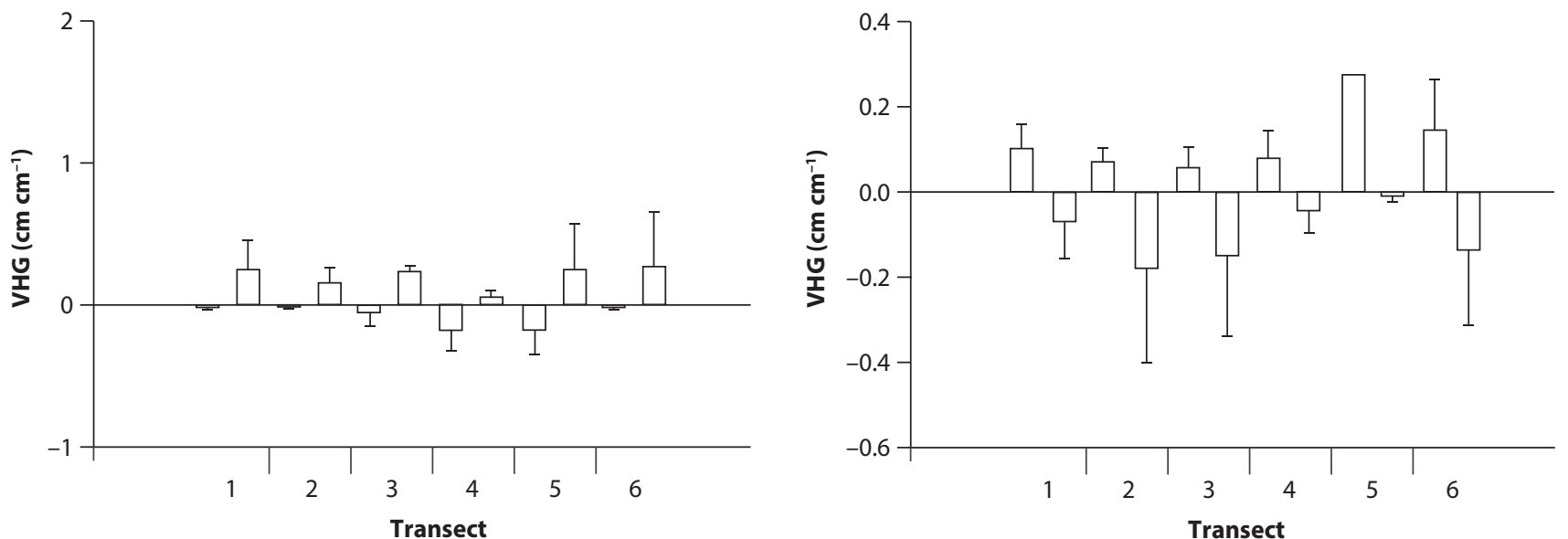

Fig. 2 Longitudinal variation in the hydraulic gradient (VHG) in up/down welling zones in the control (a) and altered (b) sections of the river.
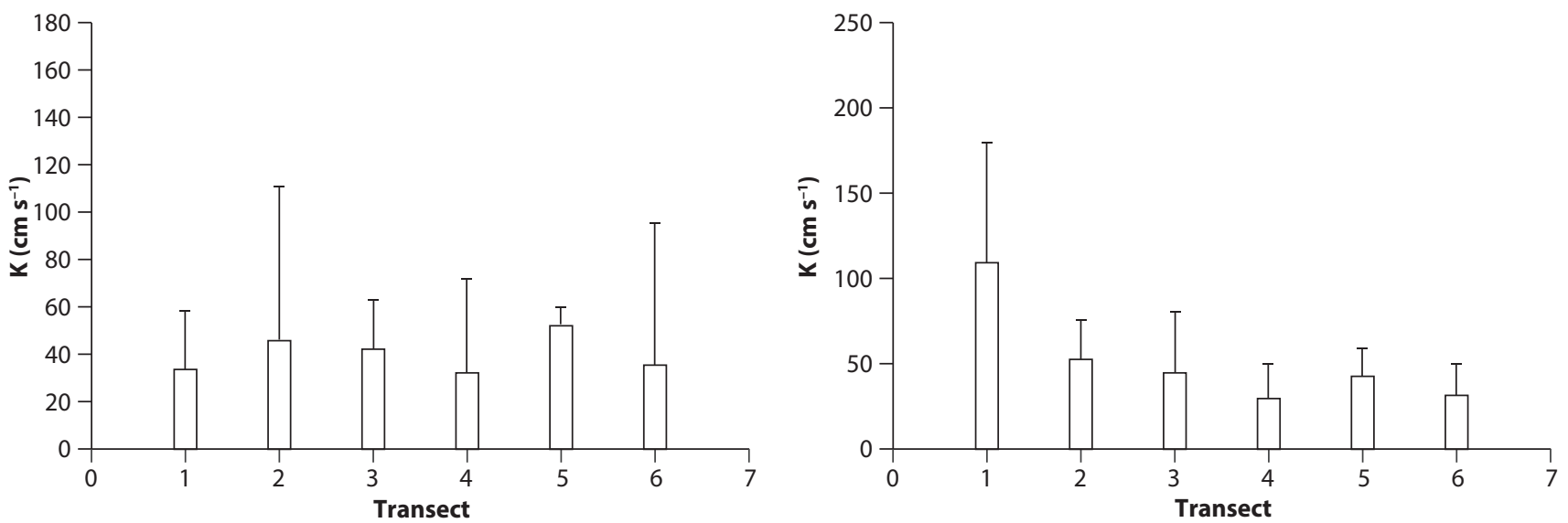

Fig. 3 Longitudinal variation in the hydraulic conductivity (K) recorded in the control (a) and altered (b) sections of the river. 
The value of the specific conductivity was on average higher in the altered $\left(215.0 \mu \mathrm{S} \mathrm{cm}^{-1}\right)$ than in the control section of the river $\left(155.74 \mu \mathrm{S} \mathrm{cm}^{-1}\right)$. Similar conductivity means were recorded in upwelling and downwelling zones in both sections of the river probably because the values were very variable (Table 2). In general terms, there was a tendency towards higher conductivity values in the hyporheic zone compared to the surface water, especially in the control section of the river (Fig. 4). This tendency was not, however, significant $(p>0.05)$. On the other hand, a reduction in the conductivity in both sections was recorded as the warmer months approached. The water in the hyporheic zone was significantly warmer than that of the surface layer in the control section (paired $t$-test, $p<0.05)$ with a mean temperature of between $9.7^{\circ} \mathrm{C}$ in January and $19.9^{\circ} \mathrm{C}$ in July (Fig. 5). The altered section of the river was generally warmer than the control section with mean temperatures of between $10.5^{\circ} \mathrm{C}$ in January and $21.2^{\circ} \mathrm{C}$ in July. The hyporheic water in this section again tended to be warmer than that of the surface layer, although these differences were not significant (Fig. 5).

\section{Spatial Variation in Nutrient Concentrations}

There were no significant differences in the mean concentrations of $\mathrm{PO}_{4}-\mathrm{P}, \mathrm{NO}_{3}-\mathrm{N}$ and $\mathrm{NH}_{4}-\mathrm{N}$ in the upwelling and downwelling zones in the control section of the river. In the altered section, however, the concentrations of $\mathrm{NO}_{3}-\mathrm{N}$ in the upwelling zones were greater than in the downwelling zones, and the mean concentrations of $\mathrm{PO}_{4}-\mathrm{P}$ were lower in the upwelling zones than the downwelling zones (Table 2). In all of the zones, the concentrations of $\mathrm{NO}_{3}-\mathrm{N}$ and $\mathrm{NH}_{4}-\mathrm{N}$ were generally more variable than the mean concentrations of $\mathrm{PO}_{4}-\mathrm{P}$. The interstitial water was richer in $\mathrm{NO}_{3}-\mathrm{N}$ and $\mathrm{NH}_{4}-\mathrm{N}$ than the surface water in the altered section of the river. During the course of this study the concentrations of $\mathrm{NO}_{3}-\mathrm{N}$ in the interstitial water in the altered section of the river were close to $10 \mathrm{mg} \mathrm{l}^{-1}$, three times greater than the concentrations of $\mathrm{NO}_{3}-\mathrm{N}$ in the surface water. The hyporheic
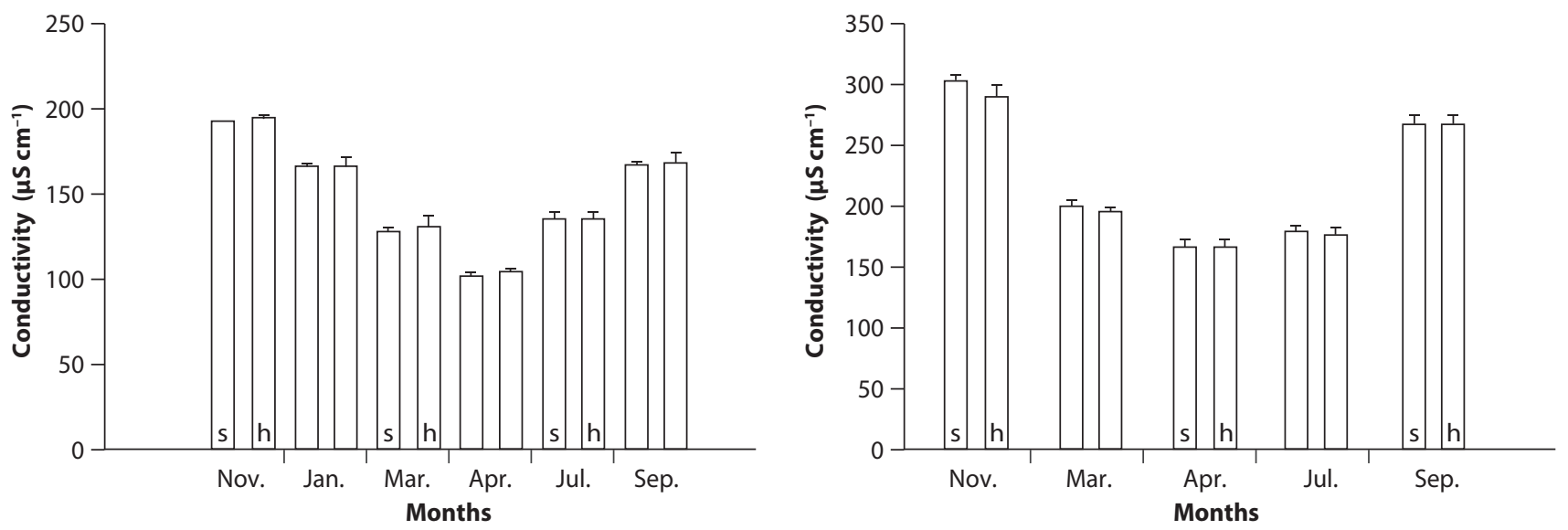

Fig. 4 Seasonal variation in the specific conductivity recorded at the surface and in the hyporheos in the control (a) and altered (b) sections of the river. Differences are not significant ( $\mathrm{s}=$ surface, $\mathrm{h}=$ hyporheos).
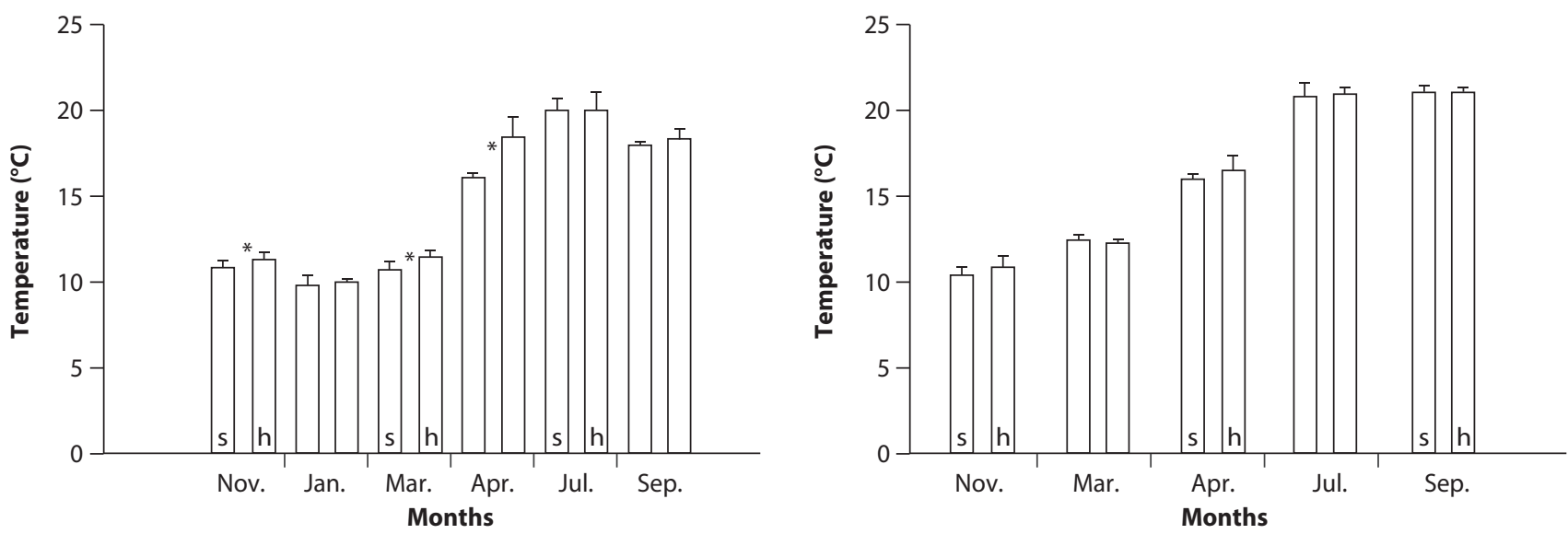

Fig. 5 Mean seasonal variation in the temperature recorded at the surface and in the hyporheos in the control (a) and altered (b) sections of the river $(*$ significant differences) $(\mathrm{s}=$ surface, $\mathrm{h}=$ hyporheos $)$. 

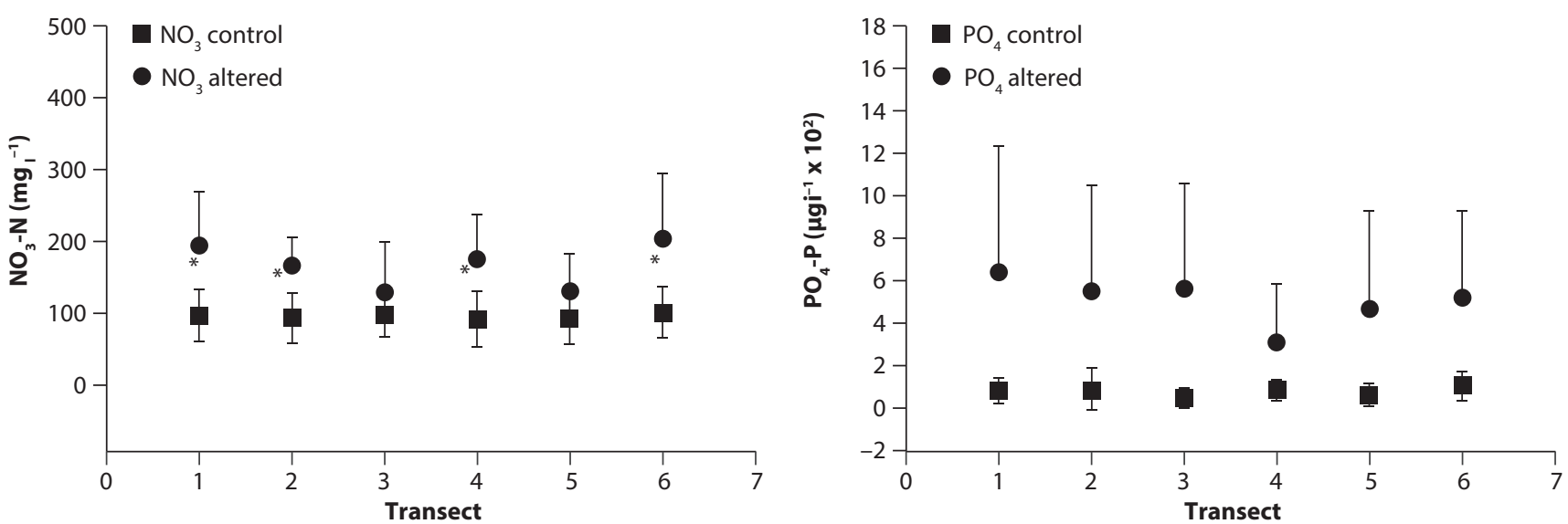

Fig. 6 Longitudinal variation in the mean hyporheic nitrate (a) and phosphate (b) concentrations recorded in the two sections river during the course of this study $\left({ }^{*}=\right.$ significant differences).
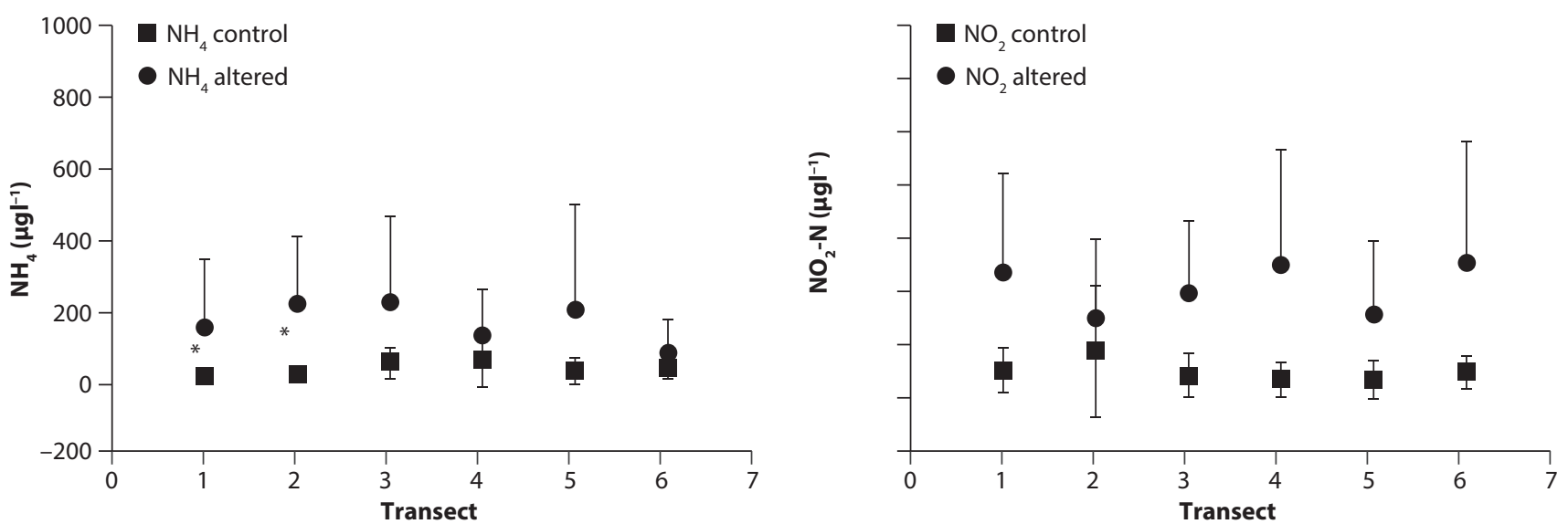

Fig. 7 Longitudinal variation in the mean hyporheic ammonium (a) and nitrite (b) concentrations recorded in the two sections during the course of this study $\left(^{*}=\right.$ significant differences).

concentrations of $\mathrm{NH}_{4}-\mathrm{N}$ were close to 45 and $200 \mu \mathrm{g} \mathrm{l^{-1 }}$ for the control and altered sections, respectively, again much greater than those recorded for the surface water. The longitudinal variation in the interstitial concentrations of $\mathrm{NO}_{3}-\mathrm{N}, \mathrm{PO}_{4}-\mathrm{P}$ and $\mathrm{NO}_{2}-\mathrm{N}$ in the altered section of the river were similar, with a slight reduction along the lengths of the upper transects and a slight increase towards the lower transects (Figs. 6 and 7). In contrast, the pattern in the concentrations of interstitial ammonium was the reverse (Fig. 7), i.e., a tendency to increase along the upper transects and decrease towards the lower transects. In the control section of the river, there were no variations in the concentrations of these ions recorded along the longitudinal gradient. There were significant differences ( $p<0.05$, paired $t$-test) for nearly all of the comparisons of ionic concentrations in the two sections of the river.

\section{Composition of the Meiofauna (Hyporheos)}

A total of 24 taxa of hyporheic organisms caught in the three transects in each of the two sections of the river were identified. The most abundant groups of organisms were Oligochaeta, Chironomidae, Nematoda, Cyclopoida and Ephemerellidae (Table 3). The Dipterans were represented by four families: Chironomidae, Ceratopogonidae, Empididae and Simuliidae. The Ephemeropterans by two families: Ephemerellidae and Leptophlebiidae and the Syncarids by an extremely rare family: Parabathynellidae. Most of the Copepods belonged to the genus Acanthocyclops sp.

More groups of organisms were recorded in the control section of the river than the altered section with a maximum of 18 and a minimum of 12 taxa in the three transects studied. The lower transect (No. 6) in the altered section had the highest Shannon-Weaver diversity index (2.86), whilst in the upper transects the highest diversity index was recorded in the control section of the river, which is similar to the pattern recorded for group richness. Jaccard's index of similarity revealed a greater resemblance in community composition in the two sections in transect six (0.59) than in the other transects (0.50 and 0.36 ) (Table 3$)$. 
Table 3 Abundance of hyporheic organisms and community parameters recorded in each transect in the control and altered sections of the river

\begin{tabular}{|c|c|c|c|c|c|c|c|}
\hline \multirow{4}{*}{\begin{tabular}{|l} 
Transect \\
Taxa \\
\end{tabular}} & & \multicolumn{6}{|c|}{ Abundance range $^{a}$} \\
\hline & & \multicolumn{2}{|c|}{1 (upper) } & \multicolumn{2}{|c|}{3 (middle) } & \multicolumn{2}{|c|}{6 (lower) } \\
\hline & & \multicolumn{6}{|c|}{ Section } \\
\hline & & Contr. & Alter. & Contr. & Alter. & Contr. & Alter. \\
\hline Platyhelminthes & Platy & & & & 1 & & 2 \\
\hline Nematoda & Nema & 3 & 3 & 3 & 3 & 3 & 3 \\
\hline Rotatoria & Rot & 2 & 2 & 2 & 1 & & 1 \\
\hline Tardigrada & Tard & & & & 1 & & \\
\hline Oligochaeta & Olig & 3 & 3 & 4 & 4 & 3 & 4 \\
\hline Hirudínea & Hir & 1 & & & 2 & & \\
\hline \multicolumn{8}{|l|}{ Gastropoda: } \\
\hline Planorbidae & Plano & 2 & & & & & \\
\hline \multicolumn{8}{|l|}{ Ostracoda. } \\
\hline Candoninae & Cand & 1 & 1 & & 1 & 1 & 2 \\
\hline \multicolumn{8}{|l|}{ Cladocera: } \\
\hline Alona sp. & Alo & 2 & & 3 & 1 & 2 & 2 \\
\hline \multicolumn{8}{|l|}{ Amphipoda: } \\
\hline Niphargus sp. & Niph & & & 2 & & 2 & \\
\hline \multicolumn{8}{|l|}{ Copepoda: } \\
\hline \multicolumn{8}{|l|}{ Cyclopoida: } \\
\hline Acanthocyclops sp. & Acan & 3 & 2 & 4 & 2 & 4 & 3 \\
\hline \multicolumn{8}{|l|}{ Harpacticoida: } \\
\hline Bryocamptus sp. & Bryo & 2 & & 1 & & 3 & 3 \\
\hline \multicolumn{8}{|l|}{ Syncarida: } \\
\hline Parabathynellidae & Parab & & & & & 3 & \\
\hline Acari & Acar & 1 & 1 & 2 & & 2 & 2 \\
\hline Collembola & Coll & & & & & & 3 \\
\hline \multicolumn{8}{|l|}{ Coleoptera: } \\
\hline Haliplidae & Hali & 1 & & 3 & & & \\
\hline \multicolumn{8}{|l|}{ Diptera: } \\
\hline Chironomidae & Chiro & 4 & 4 & 4 & 3 & 4 & 4 \\
\hline Ceratopogonidae & Cera & 1 & 1 & & & 2 & \\
\hline Empididae & Empi & 1 & & & & & \\
\hline Simuliidae & Sim & 1 & & & & & \\
\hline \multicolumn{8}{|l|}{ Ephemeroptera: } \\
\hline Ephemerellidae & Eph & 3 & 2 & 2 & & 3 & 1 \\
\hline Leptophlebiidae & Lep & & 2 & 3 & 3 & 2 & 3 \\
\hline \multicolumn{8}{|l|}{ Heteroptera: } \\
\hline Pleidae & Ple & & & & & 1 & \\
\hline \multicolumn{8}{|l|}{ Plecoptera: } \\
\hline Chloroperlidae & Chlo & 1 & & & & & \\
\hline \multicolumn{8}{|c|}{ Community parameters } \\
\hline Taxa richness (S) & & 18 & 10 & 12 & 11 & 14 & 13 \\
\hline BMWP b & & 46 & 29 & 35 & 28 & 37 & 34 \\
\hline Diversity index $\left(\mathrm{H}^{\prime}\right)$ & & 2.59 & 2.23 & 2.54 & 2.29 & 2.45 & 2.86 \\
\hline $\begin{array}{l}\text { Jaccard's index } \\
\text { (contr. vs alter.) }\end{array}$ & & 0.50 & & 0.36 & & 0.59 & \\
\hline
\end{tabular}




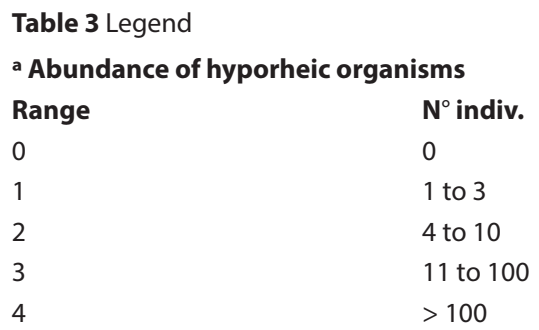

The rarest or scarcest groups amongst the aquatic organisms in the hyporheic fauna were the Tardigrades collected in transect No. 3 in the altered section of the river; Gastropoda (Planorbidae) in transect No. 1 in the control section; Syncarids (Parabathynellidae) in transect No. 6 in the control section; Collembola in transect No. 6 in the altered section; Diptera (Empididae and Simuliidae) in transect No. 1 in the control section and Heteroptera (Pleidae) in transect No. 6 in the control section.

In terms of the BMWP (Biological Monitoring Working Party) biological index for water quality, the control section of the river had the highest values (Table 3 ) with transect No. 1 having the highest index (46). The lowest values were recorded in transect No. 1 in the altered section of the river with an index of 29 and transect No. 3 with an index of 28. According to the BMWP scoring system for the evaluation of water quality the control and altered sections of the La Tordera River are classified as polluted and heavily polluted, respectively. The decrease in water quality down river of the discharge point of the sewage plant was determined on the basis of the absence of the following families of aquatic insects: Ceratopogonidae, Empididae and Haliplidae.

The highest Shannon Weaver diversity index recorded in transect No. 6 in the altered section of the river (2.86) corresponded to the highest values of the Vertical Hydraulic Gradient $\left(0.273 \mathrm{~cm} \mathrm{~cm}^{-1}\right)$, specific conductivity $\left(185.2 \mu \mathrm{S} \mathrm{cm}^{-1}\right)$, temperature $\left(22.2^{\circ} \mathrm{C}\right), \mathrm{PO}_{4}-\mathrm{P}$ $\left(5.35 \times 10^{2} \mu \mathrm{gl}^{-1}\right)$ and $\mathrm{NO}_{3}-\mathrm{N}\left(23.3 \mathrm{mgl}^{-1}\right)$. Nevertheless,

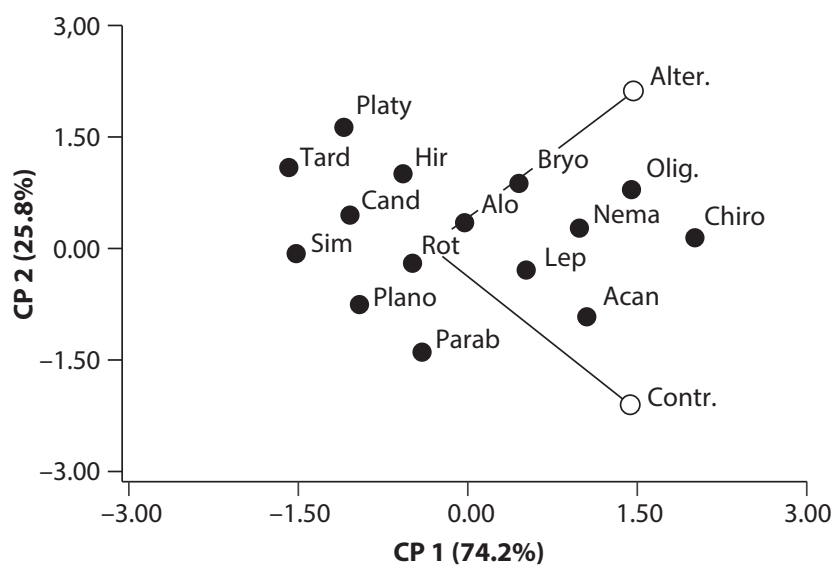

Fig. 8 Between-groups principal component analysis (PCA) of hyporheic meiofauna using $\log (x+1)$ transformed data (Alter = altered section; Contr. $=$ control section $)$.

\begin{tabular}{ll} 
b Water quality in terms of the BMWP index \\
Water quality & BMWP \\
Pristine water & $>100$ \\
Clean, but slightly polluted water & $61-100$ \\
Polluted water & $36-60$ \\
Very polluted water & $16-35$ \\
Extremely polluted water & $<15$ \\
\hline
\end{tabular}

transect No. 1 in the control section of the river had the second highest diversity index (2.59) and was the highest in hyporheic organism richness (18 groups). In contrast to transect No. 6 in the altered section, however, these values corresponded to the lowest for $\mathrm{PO}_{4}-\mathrm{P}$ concentrations $\left(0.9 \times 10^{2} \mu \mathrm{g} \mathrm{l}^{-1}\right), \mathrm{NO}_{3}-\mathrm{N}\left(12.63 \mathrm{mg} \mathrm{l}^{-1}\right), \mathrm{NH}_{4}-\mathrm{N}$ $\left(0.3 \mu \mathrm{g} \mathrm{l}^{-1}\right)$ and $\mathrm{NO}_{2}-\mathrm{N}\left(70.52 \mu \mathrm{g} \mathrm{l}^{-1}\right)$. It is important to note that the values given in Table 3 are the results for only one sample collected in July, which precludes more consistent and robust correlations. Thus, we can only speak in terms of tendencies and a preliminary characterization of the meiofauna in these two sections of the river. In general, the altered section of the river had higher nutrient concentrations and lower biological indices of water quality than the control section.

\section{Ordination Analyses}

The between-sections PCA was significant $(p=0.019)$ and indicated that $99 \%$ of the total variance in the taxonomic data was explained by spatial variation (Fig. 8) (axis $1=74.2 \%$; axis $2=25.8 \%$ ). Axis 1 was best explained by a positive relationship with Chironomidae, Oligochaeta, Nematoda, Acanthocyclops sp., Leptophhebiidae, Bryocamptus sp. and Alona sp. and a negative relationship with Planorbidae and Rotifera. Axis 2 was positively related to Platyhelminthes, Tardigrada and Candoninae, and negatively to Parabathyneliidae and Acanthocyclops sp. There was a clear separation between taxa recorded in the control section (Parabathyneliidae and Acanthocyclops) and those recorded in the altered section (Chironomidae, Oligochaeta, Nematoda).

\section{Discussion}

\section{Surface - Hyporheos Interactions}

The exchange processes between the surface and the hyporheos in the La Tordera River are clearly related to the spatial-temporal variations in the vertical hydraulic gradient and hydraulic conductivity. The spatial alternation of upwelling and downwelling zones in both sections of the river indicate the geomorphology is similar in both sections of the river; the river bed is mainly made up of coarse sediments (pebbles, stones, gravel) resulting in high values of hydraulic conductivity, especially in the control section. The changes recorded in the magnitude and direction of the hydraulic gradient could be the re- 
sult of changes in water levels and surface water discharge (Valett et al. 1994). An increase in the surface water discharge could increase the extent of the upwelling zones, whilst in dry periods the downwelling zones would increase in size (Valett et al. 1990).

The importance of the topography of the river bed in hydrological exchange processes has been demonstrated for longitudinal sections along riffle - pool sequences. Reductions in depth result in high pressure zones at the end of a pool where surface water infiltrates the sediment, displacing the interstitial water (downwelling). Later, at the extreme end of the riffle, the increase in depth results in a low pressure zone, causing the discharge or upwelling of interstitial water (Triska et al. 1989b; Brunke and Gonser 1997; Woessner 2000). Experiments done with tracers by Harvey and Bencala (1993) indicate that these convex and concave sequences along the topography of the river bed control surface - hyporheic interactions. Surface water infiltrates in downwelling zones and flows interstitially along well defined channels. After travelling up to $10 \mathrm{~m}$ downstream it returns to the surface independently of contributions from the river aquifer. The obstacles present on the river bed, such as gravel bars, rocks, pebbles, tree trunks act as dykes, and aggregations of macrophytes and even lamprey nests, can result in small scale differences in hydraulic pressure modifying interstitial water flow (Hendricks and White 1991). The lack of important topographic differences in the two sections of the La Tordera River used in this study could be the reason why the hydraulic gradient does not show a defined pattern of upwelling and downwelling zones. In contrast, the higher hydraulic conductivity recorded in the control section of the river compared to the altered section demonstrates the effect of the effluent from the sewage treatment plant. This point source of pollution results in the clogging of the hyporheic interstitial spaces causing a clear reduction in the hydraulic conductivity in the altered section of the river. The discharge of residual water, or water inefficiently or improperly treated encourages the external clogging of the river bed by favouring the growth of benthic algae or the sedimentation of fine or very fine organic particles on the river bed. Internal clogging is caused by the intrusion of organic or very fine inorganic material into the interstitial spaces in the sediment. Unsustainable activities as regards soil use in the catchment basin directly enhance this process by increasing the amount of suspended particles (seston) and sediment load (Brunke and Gonser 1997; Treese et al. 2009).

The small difference in the specific conductivity of the surface water and the water in the hyporheos zone is similar to that reported by other authors such as Hendricks and White (1991) for the Michigan River, where the hyporheic conductance was significantly higher than that of the surface water. Although the specific conductance of the hyporheos also tended to be higher than that of the surface water in this study, the differences were not significant due to the large variability between replicates.
Surface - aquifer exchange processes determine the temperature in the hyporheic zone in that the hyporheic temperature in general, varies according to the mean annual air temperature, whilst that of the river shows large daily and seasonal fluctuations. The temperatures recorded in this study clearly tended to be higher in the hyporheic zone than at the surface and these differences were significant in the control section of the river. These results agree with those reported by Valett et al. (1990) and Valett (1993) for rivers in the Sonora Desert with highly porous sediments. The temperature regimen in the hyporheic zone is important for both surface and underground aquatic systems due to the fact that fluvial microbial metabolic processes and the development of many invertebrates are thermo-dependant (Brunke and Gonser 1997).

\section{Hydrology and Nutrient Content}

The hyporheic concentrations of total inorganic nitrogen $\left(\mathrm{NH}_{4}-\mathrm{N}+\mathrm{NO}_{3}-\mathrm{N}+\mathrm{NO}_{2}-\mathrm{N}\right)$ and phosphate $\left(\mathrm{PO}_{4}-\mathrm{P}\right)$ were higher than those recorded at the surface. There were no significant differences between upwelling and downwelling zones. A large number of publications report the richness of the nutrients in the hyporheic zone (Valett et al. 1990, 1994 and 1996; Stanley and Boulton 1995; Jones Jr and Holmes 1996). There is a strong correlation between surface nitrate concentrations and the magnitude of the vertical hydraulic gradient (VHG) in upwelling zones. The results from this study indicate that contributions from nitrogen-rich interstitial waters may increase surface nitrate concentrations in upwelling zones, thus making the hyporheic zone a source of nitrates in the control section of the La Tordera River. In contrast, in the altered section of the river there is a high concentration of surface $\mathrm{NO}_{3}-\mathrm{N}, \mathrm{NH}_{4}-\mathrm{N}, \mathrm{DIN}$ and DOC as a consequence of the discharge from the wastewater treatment plant (Merseburger et al. 2005). Similar studies indicate that in these situations the hyporheic zone acts as a nutrient sink or trap (Triska et al. 1989; Jones Jr and Holmes 1996; Taleb et al. 2008). In the hyporheic zone, especially in the aerobic - anaerobic interphase, an intense metabolism of nitrogen takes place during the nitrification - denitrification processes. Both processes are related to the existing gradients of dissolved oxygen, dissolved organic carbon (DOC), ammonium and nitrates as well as flows between the surface and aquifer compartments. Allochthonous sources of nitrate entering the river may be assimilated by the epiphyton, which stimulates the growth of benthic algae. This constitutes one of the most important effects of point sources of pollution by nutrients in oligotrophic water bodies (Valett et al. 1992; Jones Jr and Holmes 1996). There were no significant differences in the phosphate concentrations between the upwelling and downwelling zones in most of the samples, although there was a tendency for them to be higher in the downwelling zone in the altered section of the river. Valett et al. (1994) report similar results for Sycamore Creek, Arizona and also establish that the 
hyporheic phosphate concentrations are not affected by the magnitude of the surface - aquifer exchange in the upwelling zones, although they were very close to being significant. The high concentrations of phosphate recorded in the hyporheic zone and their relation to the VHG indicate that the dynamics of this anion are controlled by physicochemical processes such as adsorption. Biological processes may also affect the concentrations of this anion, but in this study area are probably insignificant due to the fact that there is an excess of this nutrient, especially in the altered section of the river (Valett et al. 1990).

\section{Composition of the Meiofauna and its Relation to Hyporheic Physicochemistry}

Chironomids were the most abundant taxon in the hyporheos in the area studied, followed by Oligochaetes. These results are similar to those reported by Fraser and Williams (1998) and Franken et al. (2001) in Ontario, Canada. The number of taxa identified by these authors was also similar to that recorded in this study. Nevertheless, Rotifers, Cladocera and Syncarids recorded in the La Tordera River in this study have not been reported previously in this region (Boulton and Stanley 1995; Fraser and Williams 1998; Bartoszek 2001; Danielopol and Pospisil 2001; Franken et al. 2001). The Rotifera and Cladocera recorded in the hyporheic samples form part of the fluvial benthos, which indicates that these organisms also occasionally visit the interstitial habitat in search of food or refuge (Williams 1993). Amongst the groups identified, the Syncarids are rare and a most important find.

The multivariate analysis indicated that the species composition of the invertebrates recorded in the two sections differed. We suggest that this reflects differences in the taxa in their tolerance of pollution. Species richness and diversity did not vary greatly, possibly reflecting the rapidity with which most hyporheic sensitive taxa, such as Cyclopoida, Syncarids, Ephemeroptera and Gastropoda are replaced. The Amphipoda, Syncarida, Coleoptera, Heteroptera and Gastropoda were absent from the altered section. Belaidi et al. 2004 report that Crustacea do not occur in heavily polluted subterranean water in the Tafna stream in Algeria, which demonstrates the vulnerability of these organism to pollution and their value as indicator organism in subterranean environments. The highest richness of meiofauna was recorded in the control section of the river, where the interstitial nutrient concentrations were lowest. The meiofauna richness recorded in the aquifer discharge (upwelling) zones in all transects in both sections of the river was high. This distribution can be attributed to several factors: habitat differences, response to changes in sediment size and underflow dynamics, and to increasing hypoxia and pollution (Belaidi et al. 2004). Franken et al. 2001 and Febria et al. 2010 report a large number of groups of organisms in aquifer recharge (downwelling) zones as well as in upwelling zones. As regards the preferences of a group of organisms for a particular section of a hydraulic gradient, the results of this study are not conclusive owing to the lack of samples of the hyporheic fauna in downwelling zones.

In an attempt to determine the quality of the interstitial water in the two sections of the La Tordera River we used the BMWP (Biological Monitoring Working Party) biological index specially adapted for Mediterranean rivers (Armitage 1983; Alba-Tercedor and Sánchez-Ortega 1988), which takes into consideration the presence/absence of aquatic benthic invertebrates in the hyporheic zone. We considered it appropriate to apply this index to the hyporheos in this study because many benthic larvae occupy the hyporheic zone during part of their lifecycle, as well as those groups that permanently occupy this habitat. According to the BMWP index the control section of the river is polluted and the altered section heavily polluted. The development and application of a standardized sampling technique in this study is analogous to the establishment of sampling methods for assessing the biological quality of rivers using the BMWP/ASPT scoring system (Hawkes 1997). Although the range of BMWP scores generated from the samples collected is roughly comparable to that expected from standard benthic kick sampling, the calculated scores for the hyporheic zone are much lower. The BMWP scoring system was designed to highlight biological differences in a wide spectrum of different types of river (from high altitude torrential streams dominated by Ephemeroptera, Plecoptera and Trichoptera to sluggish, lowland rivers dominated by Chironomids and Oligochaetes). In contrast, the hyporheic zone, although not actually a natural part of that spectrum, is analogous to a highly truncated portion of it, with all samples being taken from essentially the same microhabitat, almost regardless of the character of the overlying river. The range of back-calculated values for benthic BMWP (121-171) (Prat et al. 2001) is thus much narrower than the hyporheic BMWP values recorded in this study (28-46). Within the hyporheic zone samples, therefore, it is much more likely that high BMWP scoring taxa will occur alongside low scoring taxa than would be the case in the benthos.

When the taxa richness of the benthic samples (Ortiz et al. 2006) is analyzed the BMWP index is much higher than that recorded for the hyporheic samples. This reflects the relative scarcity of benthic macroinvertebrates in the hyporheic zone, the truncated functional biodiversity for these organisms and also the dominance of meiofauna in the sample that was not collected using a standard benthos net (the mesh being too coarse). When assessing the conservation value of a site the taxonomic richness of the fauna is one of the primary measures used (Pryce et al. 2010). Of the additional (non-BMWP) taxa recovered using hyporheic techniques the majority were ubiquitous (e.g. Nematoda, Cyclopoida and Harpacticoida Copepoda, Rotatoria) (Table 3). Other groups were present in very low numbers (Tardigrada, Planorbidae, Empididae were collected in only one section). Six taxa are potential bioindicators (present in most sections): Cladocera, 
Ostracoda, Ceratopogonidae, Acari, Platyhelminhes, Hirudinea. However, little is known about their relative tolerance of pollution and disturbance and more research would be required before they could be used as bioindicators. It is also possible that they are routinely present in kick samples but either pass through the mesh or are simply too small to be recorded in the normal sample sorting procedure. Hyporheic assemblages are located at the interface between ground and surface waters and are therefore able to give an earlier warning of the ecological response of lotic ecosystems to groundwater borne pollution. Groundwater species provide the potential for biomonitoring aquifers and assessing their response to pollution (e.g. diffuse nitrogen pollution). Monitoring of hyporheic and groundwater assemblages would provide information on the health of these compartments of the lotic ecosystem and provide a more comprehensive assessment of a river's ecological status (Robertson et al. 2008). This monitoring would be particularly timely in the light of the Groundwater Directive 2006, which encourages member states to conduct research in order to provide better criteria for ensuring groundwater ecosystem quality and protection.

The effluent from the Santa María de Palautordera wastewater treatment plant contributes a high nutrient load. When $\mathrm{N}$ induces a change in the dominant form of transport $\left(\mathrm{NO}_{3}-\mathrm{N}\right)$ to the reduced form $\left(\mathrm{NH}_{4}-\mathrm{N}\right)$, this has a negative effect on stream biota, especially fish communities (Marti et al. 2004). The WWTP effluent is an important source of contamination resulting directly or indirectly in external clogging of the interstitial spaces in the sediment, reducing the available physical space for the development of the hyporheic fauna and producing an increase in benthic algal cover. The fauna in the interstitial biotope appears to be highly dependent on sediment porosity and composition. The presence of a potentially highly biodegradable biomass favours detritivors and microbial organisms over filter feeders (Table 3), resulting in a change in the composition and structure of the hyporheos (Brunke and Gonser 1997; Palmer et al. 1997; Stepenuck et al. 2002; Morais et al. 2004). In general, this community is extremely sensitive to external perturbations, and is categorized as having low resistance (Fowler and Death 2001; Sliva and Williams 2005). In addition, subterranean, lenthic and oligotrophic lotic ecosystems have a long recovery time, that is, low resilience (Stepenuck et al. 2002; Febria et al. 2009). Thus, these perturbations, principally of anthropic origin, are damaging both to the ecological equilibrium and the autoregenerating capacity of the hyporheic zone, the main link in the process of integral recovery of fluvial ecosystems.

\section{Acknowledgements}

This study was made possible thanks to the collaboration of the Department of Ecology at the University of Bar- celona (Spain). We would also like to especially thank the European Project STREAMES (EVK1-CT-2000-00081) for allowing our participation and the Agencia Española de Cooperación Internacional AECID and its MAE Grants Program for foreign students.

\section{REFERENCES}

Alba-Tercedor J, Sánchez-Ortega A (1988) Un método rápido y simple para evaluar la calidad biológica de las aguas corrientes basado en el de Hellawell (1978). Limnética 4: 51-56.

Albiol R (2002) Estudi de la dinámica hidrológica superficial a la conca de La Tordera. Projecte Ciéncies Ambientals. Universitat Autónoma de Barcelona.

Armitage P, Moss D, Wright J, Furse M (1983) The performance of a new biological water quality score system based on macroinvertebrates over a wide range of unpolluted running-water sites. Water Resour 17: 333-347.

APHA (1989) Standard methods for the examination of water and waste water. 17th edition. American Public Health Association. Washington, D.C., USA.

Bartoszek J (2001) Comparison of hyporheic organisms in two intermittent streams to assess a local disturbance. J Freshwater Ecol 16: 575-579.

Baxter C, Hauer F, Woessner W (2003) Measuring groundwater-stream water exchange. New techniques for installing mini-piezometers and estimating hydraulic conductivity. T Am Fish Soc 132: 493-502.

Belaidi N, Taleb A, Gagneur J (2004) Composition and dynamics of hyporheic and surface fauna in a semi-arid stream in relation to the management of a polluted reservoir. Ann Limnol - Int J Lim 40: 237-248.

Boulton A, Stanley E (1995) Hyporheic processes during flooding in a Sonoran desert stream. Arch Hydrobiol 134: 27-52.

Boulton A, Scarsbrook M, Quinn J, Burrell G (1997) Land use effects on the hyporheic ecology of five small streams near Hamilton, New Zealand. New Zeal J Mar Freshw 31: 609-622.

Brunke M, Gonser T (1997) (Review) The ecological significance of exchange processes between rivers and groundwater. Freshwater Biol 37: 1-33.

Cushing C, Allan J (2001) Streams. Their Ecology and Life. Academic Press. London, UK.

Danielopol D, Pospisil P (2001) Hidden biodiversity in the groundwater of the Danube flood plain national park (Austria). Biodivers Conserv 10: 1711-1721.

Datry T, Larned S, Scarsbrook M (2007) Responses of hyporheic invertebrate assemblages to large-scale variation in flow permanence and surface-subsurface exchange. Freshwater Biol 52: 1452-1462.

Febria C, Fulthorpe R, Williams D (2009) Characterizing seasonal changes in physicochemistry and bacterial community composition in hyporheic sediments. Hydrobiologia 647: 113-126.

Fellows C, Valett H, Dahm C (2001) Whole stream metabolism in two mountain streams. Contribution of the hyporheic zone. Limnol Oceanogr 46: 523-531.

Fisher S, Grimm N, Martí E, Holmes R, Jones Jr B (1998) Material spiraling in stream corridors. A telescoping Ecosystems model. Ecosystems 1: 19-34.

Fowler R, Death R (2001) The effect of environmental stability on hyporheic community structure. Hydrobiologia 445: 85-95.

Franken R, Storey R, Williams D (2001) Biological, chemical and physical characteristics of downwelling and upwelling zones in 
the hyporheic zone of a north-temperate stream. Hydrobiologia 444: 183-195.

Fraser B, Williams D (1998) Seasonal boundary dynamics of a groundwater/surface-water ecotone. Ecology 79: 2019-2031.

Fuller Ch, Harvey J (1999) The effect of trace metal reactive uptake in the hyporheic zone on reach scale metal transport in Pinal creek, Arizona. In: U.S. Geological Survey (eds) Proceedings of the technical meeting Charleston South Carolina 1: 8-12.

Harvey J, Bencala K (1993) The effect of streambed topography on surface-subsurface water exchange in mountain catchments. Water Resour Res 29: 89-98.

Hawkes HA (1997) Origin and development of the Biological Monitoring Working Party score system. Water Resour 32: 964-968.

Hendricks S, White D (1991) Physicochemical patterns within a hyporheic zone of a northern Michigan river, with comments on surface water patterns. Can J Fish Aquat Sci 48: 1645-1654.

Hill A, Labadia C, Sanmugadas K (1998) Hyporheic zone hydrology and nitrogen dynamics in relation to the streambed topography of an N-rich stream. Biogeochemistry 42: 285-310.

Jones J, Holmes R (1996) (Reviews) Surface-subsurface interactions in stream ecosystems. Trends Ecol Evol 11: 239-242.

Landon M, Rus D, Harvey F (2001) Comparison of instream methods for measuring hydraulic conductivity in sandy streambeds. Ground Water 39: 870-885.

Martí E, Sabater F (1996) High variability in temporal and spatial nutrient retention in mediterranean streams. Ecology 77: 854-869.

Martí E, Aumatell J, Godé LL, Poch M, Sabater F (2004) Nutrient retention efficiency in streams receiving inputs from Wastewater Treatment Plants. J Environ Qual 33: 285-293.

Merseburger G, Martí E, Sabater F (2005) Net changes in nutrient concentrations below a point source input in two streams draining catchments with contrasting land uses. Sci Total Environ 347: 217-229.

Morais M, Pinto P, Gilherme P, Rosado J, Antunes I (2004) Assessments of temporary streams. The robustness of metric and multimetric indices under different hydrological conditions. Hydrobiologia 516: 229-249.

Ortiz J, Martí E, Puig M (2006) Influences of a point source on the microhabitat distribution of stream benthic macroinvertebrates. Archiv für Hydrobiologie 165: 469-491.

Prat N (2001) La qualitat ecològica del Llobregat, El Besòs, El Foix i La Tordera. Informe 1999 In: Diputació de Barcelona (eds) Estudis de la qualitat ecológica dels rius (9). Institut d'Edicions, Barcelona, Spain.

Pryce D, Willby N, Givear D (2010) An investigation into the hyporheic zone of gravel bed rivers in Scotland and its associated fauna. Scottish Natural Heritage Commissioned Report No. 397.

Robertson A, Johns T, Smith J, Proudlove GS (2008) A review of the subterranean aquatic ecology of England and Wales. Environment Agency, Science report SC030155/SR20.
Sabater F, Vila P (1991) The hyporheic zone considered as an ecotone. In: Ros J, Prat N (eds) Homage to Ramon Margalef; or why there is such pleasure in studying nature. Oecolog aquatic 10: $35-43$.

Sliva L, Williams D (2005) Responses of hyporheic meiofauna to habitat manipulation. Hydrobiologia 548: 217-232.

Stanley E, Boulton A (1995) Hyporheic processes during flooding and drying in a Sonoran desert stream. Arch Hydrobiol 134: $1-26$.

Stepenuck K, Crunkilton R, Wang L (2002) Impacts of urban land use on macroinvertebrate communities in southeastern Wisconsin streams. J Am Wat Resour Ass 38: 1041-1051.

Taleb A, Belaidi N, Sanchez-Perez J, Vervier P, Sauvage S, Gagneur J (2008) The role of the hyporheic zone in the nitrogen dynamics of a semi-arid gravel bed stream located downstream of a heavily polluted reservoir (Tafna wadi, Algeria). Riv Res Appl 24: 183-196.

Treese S, Meixner T, Hogan J (2009) Clogging of an effluent dominated semiarid river. A conceptual model of stream-aquifer interactions. J Am Water Resour As 45: 1047-1062.

Triska F, Kennedy V, Avanzino R, Zellwegner G, Bencala K (1989a) Retention and transport of nutrients in a third-order stream. Channel processes. Ecology 70: 1877-1892.

Triska F, Kennedy V, Avanzino R, Zellwegner G, Bencala K (1989b) Retention and transport of nutrients in a third-order stream in northwestern California. Hyporheic processes. Ecology 70: 1893-1905.

USGS (2001) Ground water and surface water a single resource. U.S. Geological Survey Circular 1139.

Valett H, Fisher S, Stanley E (1990) Physical and chemical characteristics of the hyporheic zone of a Sonoran desert stream. J N Am Benthol Soc 9: 201-215.

Valett H, Fisher S, Grimm N, Stanley E, Boulton A (1992) Hyporheic - surface water exchange. implications for the structure and functioning of desert stream ecosystems. In: Stanford and Simons (eds) Proceedings of the first international conference on groundwater ecology, pp. 395-405.

Valett H (1993) Surface - hyporheic interactions in a Sonoran desert stream. Hydrologic exchange and diel periodicity. Hydrobiologia 259: 133-144.

Valett H, Fisher S, Grimm N, Camill P (1994) Vertical hydrologic exchange and ecological stability of a desert stream ecosystem. Ecology 75: 548-560.

Valett H, Morrice J, Dahm C, Campana M (1996) Parent lithology, surface-groundwater exchange and nitrate retention in headwater streams. Limnol Oceanogr 41: 333-345.

Williams D (1993) Nutrient and flow vector dynamics at the hyporheic/groundwater interface and their effects on the intersticial fauna. Hydrobiologia 251: 185-198.

Woessner W (2000) Stream and fluvial plain ground water interactions. Rescaling hydrogeologic thought. Ground Water 38: 423-429. 